\title{
HUBUNGAN MOTIVASI DIRI DAN PENGETAHUAN GIZI TERHADAP KEPATUHAN DIET DM PADA PASIEN DIABETES MELLITUS TIPE II RAWAT JALAN DI RSUD KARANGANYAR
}

\author{
Khairunnisa Nadya Risti ${ }^{1}$, Farida Nur Isnaeni ${ }^{2}$ \\ ${ }^{1,2}$ Program Studi Ilmu Gizi Fakultas Ilmu Kesehatan Universitas Muhammadiyah \\ Surakarta. Jl. A. Yani, Pabelan, Kartasura, Surakarta. \\ Email: 1dheanadya97@gmail.comEmail, ${ }^{2}$ farida.n.isnaeni@ums.ac.id
}

\begin{abstract}
ABSTRAK
Faktor pendukung keberhasilan menjalankan terapi diet bagi penderita diabetes mellitus yaitu motivasi diri dan pengetahuan gizi. Penelitian ini bertujuan untuk mengetahui hubungan antara motivasi diri dan pengetahuan gizi terhadap kepatuhan diet DM pada pasien diabetes mellitus tipe II rawat jalan di RSUD Karanganyar. Penelitian ini adalah penelitian observasional dengan menggunakan pendekatan Cross Sectional. Jumlah subjek sebanyak 52 responden yang diperoleh dengan cara accidental sampling. Data motivasi diri, pengetahuan gizi, dan kepatuhan diet didapatkan dari hasil kuesioner. Analisis pada penelitian ini menggunakan uji statistik Chi Square. Sebagian besar responden memiliki motivasi diri baik $(51,7 \%)$, memiliki pengetahuan gizi baik $(48,1 \%)$, dan patuh menjalankan diet $(57,7 \%)$. Ada hubungan antara motivasi diri dengan kepatuhan diet DM pada pasien DM tipe II rawat jalan di RSUD Karanganyar, dengan nilai $\mathrm{p}=0,002(\mathrm{OR}=6,222 ; 95 \% \mathrm{CI}=1,836-21,090)$. Tidak ada hubungan antara pengetahuan gizi dengan kepatuhan diet DM pada pasien DM tipe II rawat jalan di RSUD Karanganyar, dengan nilai $\mathrm{p}=0,376(\mathrm{OR}=1,651 ; 95 \% \mathrm{CI}=0,543-5,020)$.
\end{abstract}

Kata kunci: Diabetes mellitus, kepatuhan diet, motivasi diri, pengetahuan gizi.

\footnotetext{
ABSTRACT

Factors supporting the success of diet therapy for people with diabetes mellitus that is self-motivation and nutritional knowledge. This study aimed to determine the relationship between self-motivation and knowledge of nutrition on DM diet compliance in patients with type II diabetes outpatient in RSUD Karanganyar. The research was an observational research using Cross-sectional approach. The number of subjects was 52 respondents obtained by accidental sampling. Data on self-motivation, nutritional knowledge, and dietary compliance were obtained from the questionnaire. The Chi-square was used in statistical analysis. The results showed that most of the respondents had has self-motivation with good category $(51,7 \%)$, had has a good nutrition knowledge $(48,1 \%)$, and diet compliance were $57,7 \%$. There was a relationship between self-motivation and DM diet adherence in patients with type II DM outpatient in RSUD Karanganyar, with $\mathrm{p}=$
} 
$0.002(\mathrm{OR}=6.222 ; 95 \% \mathrm{CI}=1.836-21.090)$. There was no correlation between nutritional knowledge with DM dietary compliance in patients with type II DM outpatient in RSUD Karanganyar, with $\mathrm{p}=0.376(\mathrm{OR}=1.651 ; 95 \% \mathrm{CI}=0.543-5.020)$.

Keywords: Diabetes mellitus, dietary adherence, self-motivation, nutrition knowledge,

\section{PENDAHULUAN}

Diabetes Mellitus (DM) atau yang sering dikenal sebagai penyakit gula darah merupakan penyakit gangguan metabolisme yang disebabkan karena kelenjar pankreas tidak dapat memproduksi cukup hormon insulin atau karena tubuh tidak dapat menggunakan hormon insulin dengan baik (Kemenkes RI, 2014). Menurut International Diabetes Federation (IDF) (2014) prevalensi penyakit diabetes mellitus di dunia mencapai $8,3 \%$ atau 387 juta orang di dunia hidup dengan penyakit diabetes dan jumlahnya akan meningkat sebanyak 205 juta pada tahun 2035. Kejadian tersebut merupakan hal yang perlu diperhatikan bagi masyarakat. Prevalensi diabetes di Indonesia cukup tinggi yaitu mencapai 1,5 $\%$, sedangkan untuk prevalensi penyakit diabetes mellitus di Jawa Tengah sendiri memiliki prevalensi sebesar 1,6\% (RISKESDAS, 2013).

Penyakit diabetes Mellitus (DM) diklasifikan berdasarkan penyebab, perjalanan klinik dan terapinya menjadi DM Tipe I atau DM yang tergantung insulin (IDDM), DM tipe II atau DM yang tidak tergantung dengan insulin (NIDDM), DM gestasional dan DM tipe lain. Total penderita DM, kurang lebih 90\%-95\% diantaranya menderita diabetes mellitus tipe II. Diabetes Mellitus Tipe II disebabkan karena terjadinya resistensi insulin atau penurunan jumlah produksi insulin, sehingga kadar glukosa di dalam darah meningkat (Brunner \& Suddarth, 2002). Peningkatan kadar glukosa dalam darah secara terus menerus dapat berpengaruh buruk bagi tubuh dan menyebabkan komplikasi (retinopati, neuropati, nefropati, penyakit kardio vaskuler dan komplikasi lain) sehingga dibutuhkan terapi untuk menurunkan kemungkinan terjadinya komplikasi (Buckman et al., 2010).

Terdapat empat pilar penatalaksanaan DM untuk mencegah terjadinya komplikasi yaitu : edukasi , terapi gizi medis (diet), latihan jasmani, intervensi farmakologis (Perkeni, 2011; Diabetes Care, 2015). Dalam Brunner \& Suddarth (2002), salah satu faktor untuk mencegah terjadinya komplikasi adalah patuh menjalankan diet. Terdapat beberapa hal yang mempengaruhi keberhasilan kepatuhan diet yaitu pengetahuan, motivasi, persepsi, dukungan keluarga dan keikutsertaan penyuluhan gizi (Lestari, 2012).

Pasien penyandang DM diharuskan untuk menjalankan diet untuk mengontrol kadar gula darahnya. Terapi diet yang efektif pada pasien diabetes mellitus tergantung bagaimana motivasi penderita melakukan diet DM. Mengubah gaya hidup dengan menjalankan diet teratur (mengubah apa yang dimakan dan diminum) dapat mengendalikan kadar glukosa darah (Buckman et al., 2010). Tanpa motivasi, pasien diabetes mellitus akan kesulitan untuk memenuhi hal tersebut. Selain faktor motivasi, pengetahuan juga dibutuhkan untuk mendukung keberhasilan menjalankan terapi diet (Kasznicki et al., 2016). Pengetahuan dapat diperoleh dari pendidikan, pengalaman diri sendiri maupun pengalaman orang lain dan 
lingkungan. Sehingga pengetahuan (kognitif) merupakan hal yang sangat penting dalam membentuk tindakan atau perilaku seseorang (Kholid, 2012), begitu juga dalam perilaku menjalankan diet. Semakin tinggi pengetahuan seseorang akan semakin banyak informasi dan pengetahuan yang didapat, sehingga tahu cara memilih makanan yang baik dan tepat untuk penderita diabetes mellitus dan menjaga agar tetap berperilaku hidup sehat.

RSUD Kabupaten Karanganyar, merupakan rumah sakit terbesar yang ada di Kabupaten Karanganyar, sehingga menjadi rumah sakit rujukan dengan berbagai daerah di Kabupaten Karanganyar. Pada tahun 2015, di RSUD Karanganyar, penyakit diabetes mellitus masuk dalam 10 besar penyakit rawat jalan dan menempati urutan ke-5, dengan jumlah pasien yang datang menjalani rawat jalan pada tahun 2015 sebanyak 91.485 pasien. Selain itu, pasien DM Tipe II yang melakukan rawat jalan di RSUD Karanganyar mengalami peningkatan dari tahun 2010-2015 sebanyak 43,01\%. Berdasarkan data penelitian terdahulu, sebanyak $70,2 \%$ pasien DM Tipe II memiliki pengetahuan yang baik akan tetapi memiliki tingkat kepatuhan diet yang kurang. Berdasarkan pemaparan di atas peneliti tertarik untuk melakukan penelitian tentang "Hubungan Motivasi Diri dan Pengetahuan Gizi Terhadap Kepatuhan Diet DM Pada Pasien Diabetes Mellitus Tipe II Rawat Jalan di RSUD Karanganyar".

\section{METODE PENELITIAN}

Jenis penelitian ini adalah penelitian observasional dengan menggunakan pendekatan Cross Sectional, yaitu penelitian dimana semua variabel diukur dalam waktu yang bersamaan. Penelitian ini dilakukan pada bulan Oktober 2016 di RSUD Karanganyar. Penelitian ini dinyatakan lolos etik dari Komisi Etik Penelitian Kesehatan (KEPK) Fakultas Kedokteran Universitas Muhammdiyah Surakarta dengan No:341/B.1/KEPKFKUMS/X/2016. Subjek penelitian ini adalah setiap pasien DM Tipe II rawat jalan yang memenuhi syarat ketentuan dengan jumlah sebanyak 52 orang. Pengambilan subjek penelitian dilakukan dengan teknik accidental sampling, yaitu teknik penentuan sampel berdasarkan kebetulan (siapa saja yang secara kebetulan bertemu dengan peneliti dan memenuhi kriteria inklusi dan eksklusi dapat digunakan sebagai sampel). Data motivasi diri, pengetahuan gizi dan kepatuhan diet diperoleh dari hasil wawancara dengan menggunakan panduan kuesioner yang telah disediakan peneliti. Analisis data dalam penelitian ini disajikan dalam bentuk tabel dan persentase. Uji statistik yang digunakan dalam penelitian ini adalah uji Chi Square.

\section{HASIL DAN PEMBAHASAN}

\section{Distribusi Karateristik Responden berdasarkan Jenis Kelamin, Usia, Pendidikan dan Pekerjaan}

Subjek yang digunakan dalam penelitian ini adalah Pasien DM tipe II rawat jalan di RSUD Karanganyar, sesuai dengan kriteria inklusi dan eksklusi yang telah ditentukan oleh peneliti. Berdasarkan hasil penelitian diperoleh data penelitian meliputi distribusi berdasarkan jenis kelamin, usia, pendidikan dan pekerjaan.

Distribusi karateristik responden berdasarkan jenis kelamin, usia, pendidikan dan pekerjaan dapat dilihat pada Tabel 1 berikut. 
Tabel 1. Distribusi Karakteristik Responden Berdasarkan Usia, Jenis Kelamin, Pekerjaan dan Pendidikan

\begin{tabular}{ccc}
\hline Usia (tahun) & Jumlah (n) & $\begin{array}{c}\text { Persentase } \\
(\boldsymbol{\%})\end{array}$ \\
\hline $45-50$ & 7 & 13,46 \\
$51-55$ & 7 & 13,46 \\
$56-60$ & 14 & 26,92 \\
$61-70$ & 24 & 46,15 \\
\hline Jumlah & 52 & 100 \\
\hline Jenis Kelamin & Jumlah (n) & Persentase \\
& & $\mathbf{( \% )}$ \\
\hline Laki-Laki & 16 & 30,8 \\
Perempuan & 36 & 69,2 \\
Jumlah & 52 & 100 \\
\hline Pekerjaan & Jumlah (n) & Persentase \\
& & $(\boldsymbol{\%})$ \\
\hline Buruh & 3 & 5,8 \\
IRT & 18 & 34,6 \\
Pensiunan & 8 & 15,4 \\
PNS & 6 & 11,5 \\
Tani & 6 & 11,5 \\
Tidak Bekerja & 2 & 3,8 \\
Wiraswasta & 9 & 17,3 \\
Jumlah & 52 & 100 \\
\hline Pendidikan & Jumlah (n) & Persentase \\
Terakhir & & $(\%)$ \\
\hline SD & 20 & 38,5 \\
SMP & 10 & 19,2 \\
SMA & 11 & 21,2 \\
Perguruan Tinggi & 11 & 21,2 \\
Jumlah & 52 & 100 \\
\hline & &
\end{tabular}

Pada Tabel 1 dapat diketahui bahwa persentase DM Tipe II paling banyak terjadi pada rentang umur 61-70 tahun sebanyak 24 orang $(46,15 \%)$, sesuai dengan pernyataan dari Mansjoer,dkk. (2000) bahwa kelompok usia > 40 tahun merupakan kelompok usia dengan resiko tinggi terkena DM, dan sesuai dengan Depkes RI (2005) populasi penderita diabetes mellitus tipe II terjadi pada umur $>45$ tahun. Berdasarkan Tabel 2 menunjukkan bahwa persentase perempuan penderita Diabetes Mellitus tipe II lebih besar dibandingkan dengan responden laki-laki yaitu sebanyak 36 orang $(69,2 \%)$ hal tersebut sesuai dengan pendapat Irawan (2010) yang menyatakan bahwa kejadian diabetes mellitus tipe II yang lebih banyak terjadi pada wanita dikarenakan wanita memiliki peluang peningkatan masa tubuh yang lebih besar dari laki-laki. Berdasarkan jenis pekerjaan, sebanyak 18 orang responden memiliki pekerjaan IRT (Ibu Rumah Tangga). Menurut Mongisidi (2014), pekerjaan memiliki andil terhadap kejadian DM, karena dengan memiliki pekerjaan, maka seseorang akan secara rutin melakukan aktifitas fisik sedangakan orang yang tidak memiliki pekerjaan, cenderung lebih sedikit melakukan aktifitas fisik. Aktifitas fisik yang kurang akan menyebabkan pembakaran kalori atau proses metabolisme tubuh tidak optimal hal tersebut dapat mempengaruhi kadar gula darah. Berdasarkan pendidikan menunjukkan bahwa sebagian besar responden memiliki pendidikan terakhir SD (Sekolah Dasar) yaitu sebanyak 20 responden atau $38,5 \%$.

\section{Distribusi Karakteristik Responden berdasarkan Kepatuhan Diet \\ Distribusi karakteristik responden \\ berdasarkan kepatuhan diet dapat dilihat pada Tabel 2.}

Tabel 2. Distribusi Karakteristik Responden berdasarkan Kepatuhan Diet

\begin{tabular}{ccc}
\hline Kepatuhan Diet & Jumlah (n) & $\begin{array}{c}\text { Persentase } \\
(\boldsymbol{\%})\end{array}$ \\
\hline Patuh & 30 & 57,7 \\
Tidak patuh & 22 & 42,3 \\
\hline Jumlah & 52 & 100 \\
\hline
\end{tabular}

Berdasarkan Tabel 2 didapatkan hasil sebanyak 30 responden $(57,7 \%)$ patuh dalam menjalankan diet DM dan 22 $(42,3 \%)$ responden tidak patuh menjalankan diet yang seharusnya dilakukan di rumah setiap harinya. Dilihat dari persentasenya, pasien yang menjalankan diet dengan patuh bisa dikatakan masih sedikit jika dibandingkan dengan jumlah total responden. Hal ini dapat terjadi karena, terdapat berbagai faktor yang dapat mempengaruhi seseorang untuk dapat patuh melaksanakan diet. 
Distribusi Karakteristik Responden berdasarkan Motivasi Diri

Distribusi karakteristik responden berdasarkan Motivasi Diri dapat dilihat pada Tabel 3.

Tabel 3. Distribusi karakteristik responden berdasarkan Motivasi diri

\begin{tabular}{ccc}
\hline $\begin{array}{c}\text { Motivasi } \\
\text { Diri }\end{array}$ & $\begin{array}{c}\text { Jumlah } \\
(\mathbf{n})\end{array}$ & $\begin{array}{c}\text { Persentase } \\
(\boldsymbol{\%})\end{array}$ \\
\hline Baik & 27 & 51,9 \\
Tidak Baik & 25 & 48,1 \\
\hline Jumlah & 52 & 100 \\
\hline
\end{tabular}

Berdasarkan Tabel 3 dapat dilihat hasil analisis distribusi responden menurut motivasi diri, terdapat $27 \quad(51,9 \%)$ responden yang mempunyai motivasi diri yang baik, sedangkan responden dengan motivasi diri yang tidak baik sebanyak 25 orang $(48,1 \%)$. Motivasi diri pada dasarnya berasal dari dalam diri setiap individu, akan tetapi banyak faktor yang mepengaruhinya. Pada prinsipnya, seseorang yang memiliki motivasi yang tinggi, akan berusaha mewujudkan apa yang tengah diinginkannya, misalnya pada penderita DM yang diharuskan menjalankan kepatuhan diet DM, motivasi yang tinggi mempengaruhi fikiran untuk melaksanannya dan kemudian diaplikasikan dengan terbentuknya suatu perbuatan (menjalankan diet DM), apabila berhasil orang yang bersangkutan akan merasa puas (Notoadmodjo, 2010).

\section{Distribusi Karakteristik Responden berdasarkan Pengetahuan Gizi}

Distribusi karakteristik responden berdasarkan pengetahuan gizi dapat dilihat pada Tabel 4.
Tabel 4. Distribusi karakteristik responden berdasarkan pengetahuan gizi

\begin{tabular}{ccc}
\hline $\begin{array}{c}\text { Pengetahuan } \\
\text { Gizi }\end{array}$ & $\begin{array}{c}\text { Jumlah } \\
\text { (n) }\end{array}$ & $\begin{array}{c}\text { Persentase } \\
(\mathbf{\%})\end{array}$ \\
\hline Baik & 25 & 48,1 \\
Kurang & 27 & 51,9 \\
\hline Jumlah & 52 & 100 \\
\hline
\end{tabular}

Sebagian besar responden $(51,9 \%)$ memiliki pengetahuan yang kurang. Hasil tersebut dapat terjadi karena pengetahuan dipengaruhi oleh dua faktor penting yaitu faktor internal dan faktor eksternal. Pengetahuan dapat diakumulasikan melalui internalisasi maupun eksternalisasi. Pengetahuan bisa bersifat formal maupun informal (Al-Busaidi, 2010). Faktor yang mempengaruhi pengetahuan, diantaranya adalah pendidikan yang didapatkan melalui pendidikan formal maupun non formal, media masa atau sumber informasi, sosial budaya dan ekonomi, lingkungan, serta pengalaman. Dilihat dari pemaparan Notoadmodjo (2010).

\section{Hubungan Motivasi Diri dengan Kepatuhan Diet}

Hasil uji hubungan Motivasi Diri dengan Kepatuhan Diet dapat dilihat pada tabel 5. Dari tabel 5 dapat dilihat bahwa Data persentase responden dengan motivasi diri baik dan patuh dalam menjalankan diet sebesar 77,8\%, sedangkan responden dengan motivasi diri tidak baik tetapi tetap patuh dalam menjalankan diet DM sebanyak 36,0\%.

Tabel 5. Hubungan Motivasi Diri dengan Kepatuhan Diet DM

\begin{tabular}{|c|c|c|c|c|c|c|c|c|c|}
\hline \multirow{3}{*}{$\begin{array}{c}\text { Motivasi } \\
\text { Diri }\end{array}$} & \multicolumn{4}{|c|}{ Kepatuhan Diet } & \multirow{2}{*}{\multicolumn{2}{|c|}{ Total }} & \multirow{3}{*}{ Nilai $p$} & \multirow{3}{*}{ OR } & \multirow{2}{*}{$95 \% \mathrm{CI}$} \\
\hline & \multicolumn{2}{|c|}{ Patuh } & \multicolumn{2}{|c|}{ Tidak Patuh } & & & & & \\
\hline & $\mathbf{N}$ & $\%$ & $\mathbf{N}$ & $\%$ & $\mathbf{N}$ & $\%$ & & & \multirow{4}{*}{$\begin{array}{l}1,836- \\
21,090\end{array}$} \\
\hline Baik & 21 & 77,8 & 6 & 22,2 & 27 & 100 & \multirow{3}{*}{0,002} & \multirow{3}{*}{6,222} & \\
\hline Tidak Baik & 9 & 36,0 & 16 & 64,0 & 25 & 100 & & & \\
\hline Jumlah & 30 & 57,7 & 22 & 42,3 & 52 & 100 & & & \\
\hline
\end{tabular}


Persentase responden yang memiliki motivasi yang baik namun tidak patuh dalam menjalankan diet DM sebesar $22,2 \%$ lebih sedikit dibandingkan dengan responden yang memiliki motivasi tidak baik dan tidak patuh menjalankan diet DM 64,0\%. Hasil uji korelasi dengan menggunakan chi-square menunjukan hasil $\mathrm{p}=0,002(\mathrm{p}=<0,05)$ dengan $(\mathrm{OR}=$ $6,222 ; 95 \% \mathrm{CI}=1,836-21,090)$. Dari hasil uji korelasi tersebut menyatakan bahwa Ho ditolak yang berarti terdapat hubungan antara motivasi diri dengan kepatuhan diet DM pada pasien DM tipe II rawat jalan di RSUD Karanganyar, dengan $\mathrm{OR}=6,222$ yang berarti pasien DM tipe II yang memiliki motivasi diri yang baik mempunyai peluang untuk patuh menjalankan diet DM sebesar 6,222 kali dibandingkan dengan pasien DM tipe II dengan motivasi diri yang tidak baik.

Dapat dilihat dari analisis diatas bahwa responden yang memiliki motivasi diri baik cenderung lebih patuh menjalankan diet DM yang harus dijalaninya. Sedangakan responden yang memiliki motivasi diri tidak baik akan cenderung tidak patuh dalam menjalankan diet DM. Hasil ini dikarenakan individu yang memiliki motivasi diri yang baik akan memiliki keyakinan bahwa dirinya mampu untuk melakukan tugas atau tindakan tertentu. Individu yang bertindak berdasarkan motivasi diri (intrinsik) akan lebih bertahan dibandingkan dengan individu yang berprilaku berdasarkan motivasi dari luar diri (ekstrinsik) (Lestari, 2012). Sehingga, ketika petugas kesehatan (dokter, perawat dan ahli gizi) memberikan dorongan dan pengetahuan kepada pasien dengan benar, motivasi dari dalam diri pasien akan semakin kuat dan pasien akan lebih mandiri menjalankan diet dengan baik dan benar (Austin, S., et al, 2013). Hal ini sesuai dengan pernyataan responden bahwa kebanyakan dari mereka menyadari dan memiliki semangat untuk hidup lebih sehat, dengan cara salah satunya menumbuhkan motivasi dalam diri mereka sendiri dan selalu menerima saran dari petugas kesehatan. Sesuai dengan penelitian Oftedal, B.F. (2011), ketika seseorang termotifasi dengan adanya Rangsangan dari stimulus (dukungan keluarga, lingkungan, sosial) akan membentuk suatu ekspektasi (harapan) yang mempengaruhi respon (motivasi) sehingga menghasilkan sikap/perilaku (kepatuhan dalam diet) yang akan bertahan lama atau bersifat continue.

Analisis korelasi diatas sejalan dengan penelitian Indarwati dkk. (2012) yang mengatakan bahwa terdapat hubungan yang signifikan antara motivasi terhadap diet DM dan responden yang mempunyai motivasi tinggi berpeluang 7 kali untuk patuh menjalankan diet dibandingkan dengan responden dengan motivasi rendah. Dalam penelitian Purwanti (2014) juga menyatakan bahwa individu yang memiliki motivasi yang tinggi, akan terlihat dalam tindakan dan prilakunya.

\section{Hubungan Pengetahuan Gizi dengan Kepatuhan Diet DM}

Hasil uji hubungan pengetahuan gizi dengan kepatuhan diet DM dapat dilihat pada Tabel 6.

Tabel 6. Hubungan Pengetahuan Gizi dengan Kepatuhan Diet DM

\begin{tabular}{|c|c|c|c|c|c|c|c|c|c|}
\hline \multirow{3}{*}{$\begin{array}{c}\text { Pengetahuan } \\
\text { Gizi }\end{array}$} & \multicolumn{4}{|c|}{ Kepatuhan Diet } & \multirow{2}{*}{\multicolumn{2}{|c|}{ Total }} & \multirow{3}{*}{ Nilai p } & \multirow{3}{*}{ OR } & \multirow{3}{*}{$95 \% \mathrm{CI}$} \\
\hline & \multicolumn{2}{|c|}{ Patuh } & \multicolumn{2}{|c|}{ Tidak Patuh } & & & & & \\
\hline & $\mathbf{N}$ & $\%$ & $\mathbf{N}$ & $\%$ & $\mathbf{N}$ & $\%$ & & & \\
\hline Baik & 16 & 64,0 & 9 & 36,0 & 25 & 100 & \multirow{3}{*}{0,376} & \multirow{3}{*}{1,651} & \multirow{3}{*}{$\begin{array}{c}0,543- \\
5,020\end{array}$} \\
\hline Kurang & 14 & 51,9 & 13 & 48,1 & 27 & 100 & & & \\
\hline Jumlah & 30 & 57,7 & 22 & 42,3 & 52 & 100 & & & \\
\hline
\end{tabular}


Persentase responden dengan pengetahuan gizi baik dan patuh menjalankan diet DM sebesar 64,0\%, kemudian responden dengan pengetahuan gizi kurang tetapi tetap patuh menjalankan diet yaitu sebesar $51,9 \%$. Hasil analisis juga menyimpulkan bahwa responden dengan pengetahuan gizi baik tetapi tidak patuh dalam menjalankan diet DM yaitu sebesar 36,0\% dan responden dengan pengetahuan gizi kurang tetapi juga tidak patuh menjalankan diet DM lebih besar persentasinya dibanding dengan responden dengan pengetahuan gizi yang baik tetapi tidak patuh menjalankan diet DM, persentase sebesar $48,1 \%$.

Dapat dilihat dari hasil analisis diatas bahwa uji korelasi chi-square menghasilkan nilai $\mathrm{p}=0,376(\mathrm{p} \geq 0,05)$ $(\mathrm{OR}=1,651 ; 95 \% \mathrm{CI}=0,543-5,020)$ dengan kata lain Ho diterima, tidak terdapat hubungan yang signifikan antara pengetahuan gizi dengan kepatuhan diet DM pada pasien DM tipe II rawat jalan di RSUD Karanganyar dan hasil OR pada anlisis ini, pengetahuan gizi bukan merupakan faktor resiko peluang untuk melakukan kepatuhan diet DM.

Hasil analisis yang menunjukan tidak adanya hubungan yang signifikan, sesuai dengan penelitian Manan (2011) yang mengatakan bahwa tidak terdapat hubungan antara pengetahuan dengan kepatuhan diet. Selain itu, juga sejalan dengan penelitian Astuti dkk. (2015) yang mengatakan bahwa tidak ada hubungan antara pengetahuan dengan kepatuhan responden dalam menjalani diet DM tipe II.

Analisis hasil yang menunjukan
tidak adanya hubungan antara

pengetahuan gizi dengan kepatuhan diet DM dikarenakan selain pengetahuan, ada beberapa hal yang mempengaruhinya. Hal-hal yang dapat mempengaruhi kepatuhan diet diantaranya adalah lamanya responden dalam menjalankan terapi DM, karena selang waktu yang lama dengan otomatis pasien DM tipe II telah banyak menerima edukasi dari petugas kesehatan di rumah sakit sehingga dapat mempengaruhi pengetahuannya.

\section{KESIMPULAN}

1. Responden yang memiliki motivasi diri baik sebesar $51,7 \%$ dengan kata lain sebanyak 27 responden memiliki motivasi diri yang baik, dari total keseluruhan responden sebanyak 52 orang.

2. Responden yang memiliki pengetahuan gizi baik, yaitu sebanyak 25 orang responden $(48,1 \%)$ dari total responden 52 orang.

3. Responden yang menjalankan kepatuhan diet dengan patuh pada pasien DM Tipe II rawat jalan di RSUD Karanganyar sebanyak 30 orang responden dengan persentase sebesar $57,7 \%$.

4. Ada hubungan antara motivasi diri dengan kepatuhan diet DM pada pasien DM tipe II rawat jalan di RSUD Karanganyar, dengan nilai $\mathrm{p}=0,002$ $(\mathrm{OR}=6,222 ; 95 \% \mathrm{CI}=1,836-21,090)$.

5. Tidak ada hubungan antara pengetahuan gizi dengan kepatuhan diet DM pada pasien DM Tipe II rawat jalan di RSUD Karanganyar dengan nilai $\mathrm{p}=0,376(\mathrm{OR}=1,651 ; 95 \% \mathrm{CI}=$ $0,543-5,020)$

\section{DAFTAR PUSTAKA}

Al-Busaidi K.A., , Olfman, L., Ryan, T., dan Leroy, G., 2010, Sharing Knowledge to A Knowledge Management System: Examining the motivators and the benefit in an omani organization, Journal of Organization Knowledge Management, Vol. 2010. 
American Diabetes Association (ADA). 2015. Classification and Diagnosis of Diabetes Mellitus. Diabates Care. 31 (1):8-13,42-44.

Astuti, S., Paratmanitya, Y., Wahyuningsih., 2015, Tingkat Pengetahuan dan Dukungan Keluarga Tidak Berhubungan dengan Kepatuhan Menjalani Terapi Diet penderita Diabetes Mellitus Tipe 2 di Puskesmas Kasihan II Bantul Yogyakarta, Jurnal Gizi dan Dietetik Indonesia, Vol. 3, No. 2, Mei 2015: 105112.

Austin, S., Guay, F., Senecal, C., Fernet, C., Nouwen, A.,., 2013, Longitudinal testing of a dietary self-care motivational model in adolescents with diabetes, Journal of Psychosomatic Research 75 (2013) 153-159.

Brunner dan Suddarth., 2002, Buku Ajar Keperawatan Medikal Bedah , Edisi 8., EGC, Jakarta.

Buckman, R dan Mc Chris., 2010, Apa Yang Seharusnya Anda Ketahui Tentang Hidup Dengan Diabetes, PT Citra Aji Parama, Yogyakarta.

Departemen Kesehatan RI., 2005, Pharmaceutical Care Untuk Penyakit Diabetes Mellitus, Depkes RI, Jakarta.

IDF., 2014, IDF Diabetes Atlas Sixth Edition, International Diabetes Federation 2014 Update.

Indarwati, D., Rusmariana, R.A., dan Hartanti, R.D., 2012, Hubungan Motivasi dengan Kepatuhan Diet Diabetes Mellitus Pada pasien Diabetes Mellitus di Desa Tangkil Wilayah Kerja Puskesmas Kedungwuni II Kabupaten Pekalongan, Skripsi, Program Studi S1 Keperawatan, STIKES Pekajangan Pekalongan.

Irawan, D., 2010, Prevalensi dan Faktor Risiko Kejadian Diabetes Mellitus Tipe 2 di Daerah Urban Indonesia (Analisa Data Sekunder Riskesdas 2007), Tesis. Universitas Indonesia.

Kasznicki, J. Glowacka, A., Drzewoski, J., 2016, Type 2 diabetic patients compliance with drug therapy and glycaemic control, Diabetologia Doswiadczalna $i$ Kliniczna, Vol. 7, No. 4.

Kementerian Kesehatan RI., 2014, Situasi dan Analisis Diabetes, Kemenkes RI, Jakarta.

Kholid, A., 2012, Promosi Kesehatan, Rajawali Pers, ISBN 978-979-464-7, Jakarta.

Lestari, T. S., 2012, Hubungan Psikososial dan Penyuluhan Gizi Dengan Kepatuhan Diet Diabetes Mellitus Tipe 2 Rawat Jalan Di RSUP Fatmawati Tahun 2012, Skripsi, Fakultas Kesehatan Masyarakat Universitas Indonesia, Jakarta. 
Manan., 2011, Hubungan Tingkat Pengetahuan Dengan Kepatuhan Dalam Upaya Mengontrol Gula Darah Di Poliklikik RS, Immanuel Bandung, Skripsi, STIKES Santo Borromeus.

Mansjoer, A., 2000, Kapita Selekta Kedokteran. Jilid I, Media Aesculapius, Jakarta.

Mongisidi., 2014, Hubungan Antara Status Sosio-Ekonomi dengan Kejadian Diabetes Mellitus Tipe 2 di Poliklinik Interna BLU RSUP Prof. Dr. R. D. Kandou Manado, Skripsi, Fakultas kesehatan Masyarakat, Universitas Sam Ratulangi.

Notoatmodjo, S., 2010, Ilmu Perilaku Kesehatan, Rineka Cipta, Jakarta.

Oftedal, B.F., 2011, Motivation for Self-management Among Adults with Type 2 Diabetes, Tesis, Faculty of Social Sciences University of Stavanger.

PERKENI., 2011, Konsensus Pengelolaan dan Pencegahan Diabetes MellitusTipe 2 di Indonesia, PERKENI. Hlm. 14-29, Jakarta.

Purwanti, L. E., 2014, Hubungan Motivasi Dengan Efikasi Diri Pasien DM Tipe 2 Dalam Melakukan Perawatan Kaki Di Wilyah Kerja Puskesmas Ponorogo Utara, Vol. 11 No. 2.

Riskesdas., 2013, Laporan Nasional Riskesdas 2013, hhtp://litbag.depkes.go.id/. diakses tanggal 22 Mei 2015. 
JURNAL KESEHATAN, ISSN 1979-7621, Vol. 10, No. 2, Desember 2017 